\title{
A Pletora dos Congressos Médicos
}

As ciências, as artes, todos os ramos do conhecimento humano evoluem ininterruptamente. Verdades são identificadas diuturnamente e as de hoje podem destronar as de ontem. Se não acompanharmos estas descobertas, e evoluções, haverá estagnação e, obviamente retrocesso, pois, novas verdades surgirão.

Os encontros médicos com denominações variadas, Congressos, Jornadas, Eventos, são oportunidades em que estas verdades, novas ou antigas, poderão ser adquiridas ou revigoradas. São, pois, em princípio, eventos salutares.

Muitos organizam eventos. As sociedades médicas constituídas, associações, corpo clínico de hospital geral, ou universitário, têm a total liberdade de prepararem estes encontros. Aliás, deverão ser todos eles encorajados. Haverá ganho para todos os integrantes das diversas Disciplinas e Setores do Hospital. Haverá oportunidade de exposição de pequenos estudos, com observações preliminares mas que muito poderão contribuir para aquisição de novas verdades.

O que presenciamos, contudo, é verdadeira avalanche de Congressos e Eventos. O que deveria ser encontro, diríamos interno, é propalado aos quatro ventos na espera de audiência universal. O verdadeiro escopo é nebuloso, mas certamente não visa, inicialmente, ao real lucro dos participantes.

Esta seleção deverá ser direcionada para os Congressos organizados ou patrocinados por nossa grande Federação, a FEBRASGO, ou as Sociedades filiadas à FEBRASGO. Eles não visarão lucro nem promoção pessoal dos integrantes. O grande escopo é atender aos verdadeiros anseios dos participantes.

Fiquemos atentos, pois, para discernimos os bons eventos dos demais. Nesta linha de raciocínio, arrumemos as malas para o comparecimento ao $50^{\circ}$ Congresso Brasileiro de Ginecologia e Obstetrícia a ser realizado em novembro próximo em Recife. O evento organizado pela Federada de Pernambuco e patrocinado pela FEBRASGO, trará muita recompensa intelectual e diríamos também social para os venturosos participantes. Até lá.

A Diretoria 